\title{
Forage Substitution with Media Plant White Oyster Mushroom Waste Fermented to Percentage of Local Sheep Carcass
}

\author{
RinduAwaliaTarigan, Tri Hesti Wahyuni, Hamdan, Iskandar Sembiring, \\ NurzainahGinting. \\ Animal Prodution Program Study,Faculty Of Agriculture, University Of Sumatera \\ Utara, Medan 20155, Indonesia. \\ E-Mail: Rinduawaliatarigan@Gmail.Com
}

RINDU AWALIA, 2018: "Forage Substitution with Waste Media for White Oyster Mushroom Planting Fermentation on Percentage of Carcass at Local Sheep". Supervised by TRI HESTI WAHYUNI and HAMDAN.

The study aimed to determine the percentage of carcass in local sheep given the waste of fermented white oyster mushroom growing media as an alternative feed, carried out in NamoTrasi Village, Pasar VIII, October - December 2017. Using local sheep the average initial weight was $9 \pm 0.25 \mathrm{~kg}$. The design used was a completely randomized design (CRD) with 4 treatments and 5 replications namely $\mathrm{P} 0=$ grass $60 \%+$ concentrate $40 \%$. P1, P2, and P3 respectively are $45 \%, 30 \%, 15 \%$ grass, and fermented white oyster mushroom planting media waste $15 \%, 30 \%, 45 \%$ and $40 \%$ Concentrate. The results showed that the slaughter weight (kg/head) was: $13.67 ; 13,92 ; 13,81$; and 13.78. Empty body weight ( $\mathrm{kg} /$ tail): $8.98 ; 9,16 ; 9,10$; and 9.01. Carcass weight $(\mathrm{kg} /$ head): $5.23 ; 5.40 ; 5,34$; and 5.17. In the percentage of carcass (\%): 58.12; 58.97; 58.52; and 57.33. So it can be concluded that the waste of fermented white oyster mushroom growing media can substitute forage as a feed for local sheep but cannot increase the percentage of carcass component.

Keywords: Waste of white oyster mushroom planting media, fermentation, carcass, local sheep.

\section{1.introduction}

Sheep is one of the sources of meat and protein that is quite available and can be developed as a source of nutrition for the community. In general, sheep are cared for by the community traditionally with their own food and the amount that is kept relatively little by each family. To get a high percentage of carcass and good meat quality, among them is by improving feeding and determining the appropriate cutting weight.

One of the main obstacles in the production of ruminant livestock at this time is the unavailability of good quality feed ingredients and availability in a long time. This requires farmers to look for other alternatives to be able to use as ruminant feed ingredients. In its development there have been many studies that have attempted to find the right alternative to be used as ruminant feed ingredients whose nutritional content is quite good, as a substitute for grasses. As for what has been used as feed ingredients come from plantation waste, agricultural waste and food and beverage industry waste.

One of the efforts of agricultural waste that is becoming increasingly popular with the community is the cultivation of white oyster mushrooms (Pleurotusostreatus). The growing business of cultivation of oyster mushrooms, the resulting waste is increasing. Oyster mushroom growing media waste is formed due to materials or planting media of oyster mushrooms in the form of sawdust mixtures 
with other ingredients not all are used up when used to produce oyster mushrooms, but there are still remnants that are no longer effective for producing oyster mushrooms with good.

Oyster mushroom planting media waste is formed due to materials or planting media of oyster mushrooms in the form of sawdust mixture with other ingredients not all of which must be used when used to produce oyster mushrooms, but there are still remnants that are no longer effective for producing oyster mushrooms well. The waste is just thrown away, even though if we look at the preparation material, we can use the waste to feed ruminant animals, especially as a source of fiber which is expected tobeabletoincludeenergy needsforthelivestock that.

But to be used as a ration component, the waste of the white oyster mushroom growing media is still lacking, namely the high content of coarse fiber and has an unpleasant odor (typical smell of sawdust). Therefore, a method is needed to improve the quality of the waste of the oyster mushroom growing media, one of which is through fermentation technology.

The fermentation process requires microorganisms to increase the nutritional content of the ingredients. Fermentation is carried out by adding ingredients containing proteolytic, lignolytic, cellulotic, lipolytic microbes, and non-symbiotic nitrogen fixation (for example starbio). The microorganisms in doing their work need time to produce optimal growth.

\section{Place and time of research}

This research was carried out in Pasar VIII NamuTrasi Village, Hamlet VI, North Sumatra. This study lasted for two months starting from October 2017 to December 2017.

The materials used in this study include local sheep as many as 20 head with age 4-6 months and initial body weight $9 \pm 0.25 \mathrm{~kg}$. The ration consists of forage, fermented mushroom planting media waste media with a composition consisting of the planting media waste of dried oyster mushrooms, fine bran, Starbio probiotics, urea, molasses and sufficient water, and concentrates composed of fine bran, cake soybeans, coconut cake, molasses, ultra minerals and salt, Rhodallon and worm medicine.

The tool used is a cage of 20 units with a size of $1 \mathrm{mx} 0.5 \mathrm{~m}$, a place to feed and drink as much as 20 units, a white bucket measuring $15 \mathrm{~kg}$ as a fermentation place, a thermometer to determine the temperature inside and outside the cage, cutting blades to slaughter sheep, weighing capacity $50 \mathrm{~kg}$ with a sensitivity of $2 \mathrm{~kg}$ to weigh the weight of sheep, scales with a capacity of $2 \mathrm{~kg}$ with sensitivity of $10 \mathrm{~g}$ to weigh feed, cage cleaning tools, cage lighting equipment.

The research method used a completely randomized design (CRD) with four types of treatment (P0, P1, P2, and P3). In each treatment three repetitions were carried out. Each replication consisted of one sheep, so the total amount used was 20 rams.

The treatment ration was given in the form of four levels of balance of use of fermented oyster mushroom planting media waste for 21 days as a base material for replacing grass in complete feed as follows:

P0: Forage $60 \%+$ Concentrate $40 \%$

P1: Forage $45 \%+15 \%$ fermented white oyster mushroom media $+40 \%$ concentrate

P2: $30 \%$ forage $+30 \%$ fermented white oyster mushroom media $+40 \%$ concentrate

P3: Forage $15 \%+45 \%$ fermented white oys ter mushroom media $+40 \%$ concentrate

The experimental mathematical model used is a complete randomized design (CRD):

$\mathrm{Yij}=\mu+\sigma \mathrm{i}+\mathrm{Cij}^{\mathrm{i}}$

Information:

Yij $=$ Response or observation value from the first treatment and the jth test

$\mathrm{i}=1,2,3 \ldots=$ treatment

$\mathrm{j}=1,2,3 \ldots=$ repeat

$\mu=$ Common middle value

$\sigma i=$ Effect of the i-treatment

$\epsilon \mathrm{ij}=$ Effect of error (Experimental Error) 


\section{Research Implementation}

The study was carried out in 3 months consisting of two stages of research. Preparation phase for two weeks for the period of environmental adaptation and adjustments to the treatment feed. The second stage is the stage of data collection for 12 weeks. After the research adaptation period, weighing sheep body weight as the initial body weight of the study was carried out. At the research stage data collection was carried out including daily consumption data and weighing once every two weeks.

\section{Making Waste of Planting Media for White Oyster Mushrooms}

Mushroom planting media waste is spread over tarpaulin and then dried for 1-2 days. Dry waste is added with rice bran (5\%), Strabio ${ }^{\circledR}(0.6 \%)$, molasses $(3 \%)$ and urea $(0.6 \%)$ and also enough water then stirred. After the mixture is evenly put into plastic then compacted until anaerobic state is created. Then tied and coated again with plastic 3 times after being tied, stored in accordance with the treatment time.

\section{Data retrieval}

Data is taken after the prescribed sheep slaughter. Data retrieval is done by weighing and measuring the parameters that have been determined. Preparations are made to obtain the carcass as follows.

1. Mastery, sheep are fasted for twelve hours to empty the contents of the rumen and reduce the contents of the digestive tract.

2. Cutting, the sheep are cut at the neck until they break the trachea, jugular veins, carotid artery and esophagus.

- Final Weight

The final weight is the body weight of the cattle before fasting

- Cut weight (g/tail)

Cutting weight is body weight after fasting for 12 hours just before the sheep are slaught ered

- Blank Body Weight

Empty body weight is the weight of the cut of the cattle minus the amount of contents of the digestive tract, bladder (urine)

- Carcass Weight (g/tail)

Carcass weight is measured by weighing the sheep after being slaughtered after being reduced by the head, blood, lower four legs, skin and inside contents (rumen, intestines, kidneys, lungs and liver)

- Carcass percentage (g/tail)

Carcass percentage is calculated by dividing the carcass weight by an empty body weight, then multiplying $100 \%$

\section{Result and discussion}

\subsection{Carcass}

Carcass weight is the weight obtained from the difference in body weight after fasting (cut weight) with the weight of blood, head, feet, skin, internal organs, reproductive organs and tail. Data on average carcass weight of carcass weight Cut weight. Cut weight is obtained from the results of weighing the final weight of the sheep after fasting for 12 hours before slaughtering, this is done to empty the contents of the digestive tract. The average slaughter weight of sheep, statistically shows that the analysis of the diversity of local sheep weight weights is relatively the same or there is no striking difference from all treatments. This is because the waste of fermented white oyster mushroom growing media on each treatment gives an effect on the digestive tract contents in sheep where the level of fermented white oyster mushroom planting media waste has been optimum so that there is no difference due to the fulfillment of nutrients needed by livestock. This is consistent with the opinion of Siregar [1], 
which states that ruminant rations are generally forages and concentrates, giving rations in the form of a combination of the two ingredients will provide an opportunity for the fulfillment of nutrients.

\subsection{Empty body weight}

The weight of the empty body is obtained from the weight of the cut minus the contents of the digestive tract and urine. Where the average body weight is empty. This is presumably because the feed given to the treatment has the same quality to be digested by livestock. This is in accordance with the statement of Adiwinarti[2], which states that forage as the main feed of sheep is generally less able to meet production needs, therefore it is necessary to strengthen feed (concentrate). Besides that the same amount of nutrient consumption will produce the same cutting weight. In addition to cutting weight, it turns out that empty body weight will also affect it.

of each treatment shows different results, it is assumed that this is influenced by the weight of the sheep slaughter, where the slaughter weight of the sheep is affected by the nutritional content and composition of the feed consumed by the sheep. This is in accordance with Herman'[3], statement which states that the higher the cut weight obtained, the higher the carcass weight and the higher percentage of carcass. Sheep carcass weight is also affected by the age of the cattle, where the age of the cattle used is almost uniform. This is in accordance with Owen's[4], which states increasing carcass weight production.

\section{3 percentage of carcass}

The percentage of sheep carcass is obtained from the ratio of carcass weight with empty body weight multiplied by $100 \%$. The average percentage of carcass is affected by carcass results, while the carcass yield itself is influenced by the weight of the carcass. This is in accordance with Herman's[5] statement which states that the higher the cut weight obtained, the higher the carcass weight and the higher percentage of carcass.

The results of the study on cut weight, empty body weight, carcass weight and percentage of local sheep carcass can be recapitulated in Table 14 .

Table 14. Recapitulation of results of forage substitution research with fermented white oyster mushroom growing media on the percentage of carcass in local sheep

\begin{tabular}{lcccc}
\hline & \multicolumn{3}{c}{ Parameters } \\
\cline { 2 - 5 } Treatment & Cutweight $(\mathrm{g})$ & $\begin{array}{l}\text { BlanBody } \\
\text { Weight }\end{array}$ & $\begin{array}{l}\text { Carcass } \\
\text { Weight }\end{array}$ & $\begin{array}{c}\text { Carcass } \\
\text { percentage }\end{array}$ \\
\hline P0 & $13,67^{\text {tn }}$ & $8,98^{\text {tn }}$ & $5,23^{\text {tn }}$ & $58,12^{\text {tn }}$ \\
P1 & $13,92^{\text {tn }}$ & $9,16^{\text {tn }}$ & $5,40^{\text {tn }}$ & $58,97^{\text {tn }}$ \\
P2 & $13,81^{\text {tn }}$ & $9,10^{\text {tn }}$ & $5,34^{\text {tn }}$ & $58,52^{\text {tn }}$ \\
P3 & $13,78^{\text {tn }}$ & $9,01^{\text {tn }}$ & $5,17^{\text {tn }}$ & $57,33^{\text {tn }}$ \\
\hline
\end{tabular}

Information.tn $=$ not real

Based on the results of the above recapitulation, it was found that forage substitution with fermented white oyster mushroom planting media which was used as feed did not have a significant effect (P> 0.05) on the percentage of cut weight, empty body weight, carcass weight and carcass weight percentage on local sheep.

\section{Conclusion}

The waste of fermented white oyster mushroom growing media can substitute forage as a feed for local sheep, but it cannot increase the percentage of carcass. 


\section{Reference}

[1]Siregar, S. B. 1994. Ruminant Animal Ration. Self-helpers. Jakarta.

[2]Adiwinarti. R., C.M.S. Lestari, E. Riyantodan J.A. Prawoto. 1999. Characteristics of carcasses and non-carcasses of sheep given additional soybean industry waste feed with different levels. Anthropology journal

[3]Herman, R. 1993. Comparison of Growth, Body and Carcass Composition between Priangan Sheep and Fat Tail.Dissertation. Post Graduate Program of Bogor Agricultural University, Bogor. Yogyakarta

[4]Owen, J. B. 1977. Complet Diets for cattle and Sheep. Farming Press Ltd., Suffolk, England. 